\title{
Genetic heterogeneity of Escherichia coli strains isolated from raw milk, Minas Frescal cheese, and food handlers
}

\author{
[Heterogeneidade genética de cepas de Escherichia coli isoladas de leite cru, queijo \\ Minas Frescal e manipuladores] \\ M.R.H. Campos ${ }^{1}$, M.C.D.P.B. André ${ }^{2}$, L.J. Borges ${ }^{2}$, A. Kipnis ${ }^{2}$, \\ F.C. Pimenta ${ }^{2}$, A.B. Serafini ${ }^{3}$ \\ ${ }^{1}$ Faculdade de Nutrição - UFG - Goiânia, GO \\ ${ }^{2}$ Instituto de Patologia Tropical e Saúde Pública - UFG - Goiânia, GO \\ ${ }^{3}$ Universidade Federal de Santa Catarina - Florianópolis, SC
}

\begin{abstract}
From February 2004 to March 2005, 140 samples of food handlers - hands and nostrils - (92), raw milk (24), and minas frescal cheese (24) were analyzed for the presence of Escherichia coli in a dairy processing plant of Goiás State. Forty-seven E. coli strains were obtained and compared by DNA macrorestriction patterns obtained from pulsed-field gel electrophoresis following $X b a$ I restriction in order to investigate the possible sources of cheese contaminations. Based on PFGE genotyping, one strain isolated from food the hands of a handler and five strains isolated from raw milk were identical or closely related to six strains from cheese suggesting, in these cases, the probable source of $E$. coli contamination in cheeses. No strain isolated from the nostrils was related to those found in cheeses or milk strains. The results showed high diversity among the strains, demonstrating a lack of predominance of an endemic clone in the dairy plant. This paper highlights the usefulness of PFGE as an epidemiological tool for determining the source of $E$. coli contamination in the food industry.
\end{abstract}

Keywords: Escherichia coli, pulsotypes, minas frescal cheese, raw milk, food handlers

\section{RESUMO}

Durante um ano, de fevereiro de 2004 a março de 2005, 140 amostras retiradas das mãos e das narinas de manipuladores de alimentos (92), do leite cru (24) e do queijo-de-minas frescal (24) foram analisadas para a presença de Escherichia coli, em um laticínio do Estado de Goiás. As 47 cepas obtidas foram comparadas por macrorrestrição do DNA com enzima Xbal, seguida de eletroforese em gel em campo pulsado (PFGE), a fim de investigar as possiveis fontes de contaminação do queijo. Baseado na genotipagem pelo PFGE, uma cepa obtida do leite cru e cinco cepas obtidas dos manipuladores mostraram similaridade maior que $80 \% \mathrm{com}$ seis cepas isoladas do queijo, denotando forte correlação genética entre elas e sugerindo, nestes casos, a fonte provável de contaminação do produto final. Nenhuma cepa isolada do nariz foi relacionada às isoladas do queijo ou do leite. Os resultados mostraram grande diversidade entre as cepas, demonstrando ausência de um clone endêmico no laticínio avaliado. Este estudo destaca a utilidade do PFGE como uma ferramenta importante em investigações epidemiológicas e na determinação de possíveis fontes de contaminação por E. coli na indústria de alimentos.

Palavras-chave: Escherichia coli, PFGE, queijo Minas Frescal, leite cru, manipuladores

Recebido em 4 de dezembro de 2008

Aceito em 28 de agosto de 2009

Endereço para correspondência (corresponding address)

Rua 227, Qd 06, s/n, Setor Leste Universitário, Goiânia, GO, Brasil.

E-mail: raq7@brturbo.com.br 


\section{INTRODUCTION}

Many enteropathogenic microorganisms have been found in milk and dairy products such as cheese, which is usually stored under inadequate temperatures and consumed without any prior thermal treatment. They are frequently associated to outbreaks of foodborne diseases (Almeida Filho and Nader Filho, 2002).

Minas frescal cheese is widely consumed and has become part of the daily diet in many States of Brazil (Câmara et al., 2002; Cardoso and Araújo, 2004). This kind of cheese is produced from raw or pasteurized cow milk and because of several factors such as humidity content, its animal origin, and especially because it is hand manufactured, it can be easily contaminated and constitutes a favorable environment for bacterial survival and multiplication (Câmara et al., 2002).

The detection of coliform bacteria, especially Escherichia coli, in processed foods is an indication of fecal matter contamination. It also evidence the inadequate control of the raw material, the contamination of the handler involved in the production process, and the poor quality of the finished product. The fact that $E$. coli serogroups, whose pathogenicity is known by their toxigenic and infectious mechanisms (Câmara et al., 2002), can be isolated from cheese, also suggests that other enteropathogenic microorganisms could possibly be present in this food as well (Ritter et al., 2001).

Epidemiological studies have seek to establish the source of microorganisms in food by using bacterial typing techniques, characterizing strains from possible sources (animals, handlers, equipment, and others sources), and comparing them, in terms of genotype, to strains from food (Foxman and Riley, 2001). One of these methods is macrorestriction of DNA followed by pulsed-field gel electrophoresis (PFGE). This is a highly discriminatory and reproducible technique whose performance is the same or better than other techniques currently available and has been successfully applied for typing a large number of microorganisms. It is also the most effective technique for differentiating $E$. coli strains (Bidet et al., 2005).
The aims of this study were to characterize $E$. coli strains isolated from human nostrils and hands, raw milk, and cheese in a dairy processing plant by means of PFGE analysis and to investigate any relationship among the strains and the possible sources of cheese contamination.

\section{MATERIAL AND METHODS}

A total of 140 samples, 24 from raw milk, 24 from Minas Frescal cheese, 46 from anterior nostrils of food handlers, and 46 from their hands, were analyzed for the presence of $E$. coli in a small dairy plant in Goiás State, from March 2004 to February 2005. The industry was visited twice a month. The dairy plant had four workers handling milk and/or cheese. The study protocol was approved by the Ethical Committee at the Universidade Federal de Goiás and the participants gave informed consent. The hands and anterior nostrils samples were collected during each visit, from the handlers that were working on that day using the method described by Vandenbergh et al. (1999). Worker $\mathrm{n}^{\circ} 1$ was sampled 16 times $\left(\mathrm{M}^{1}, \mathrm{~N}^{1}\right) ; \mathrm{n}^{0} 2,17$ times $\left(\mathrm{M}^{2}\right.$, $\left.\mathrm{N}^{2}\right) ; \mathrm{n}^{0} 3$ just once $\left(\mathrm{M}^{3}, \mathrm{~N}^{3}\right)$ and $\mathrm{n}^{\mathrm{o}} 4$ was sampled 12 times $\left(\mathrm{M}^{4}, \mathrm{~N}^{4}\right)$. Raw milk and cheeses were sampled following methodology described by Midura and Bryant (2001).

The samples were submitted to presumptive, confirmed, and completed tests for coliforms, fecal coliforms, and E. coli according to Feng et al. (2002). From each positive plate, five colonies were tested for $E$. coli confirmation. The strains were stored at $-20^{\circ} \mathrm{C}$ in tryptic soy broth $^{1}$ with $20.0 \%$ glycerol awaiting further analysis.

The genetic pattern of $E$. coli strains was carried out by pulsed-field gel electrophoresis (PFGE) of restricted DNA, using a CHEF DRII', following the method of Pfaller et al. (1992) with modifications. Briefly, a single isolated colony was grown overnight in $\mathrm{TSB}^{1}$ at $37^{\circ} \mathrm{C}$. Cells were pelleted and resuspended in TEN buffer. The suspension was mixed with $1.2 \%$ SeaKem Gold agarose and plugs were made. They were placed in EC buffer with lysozime and incubated for $5 \mathrm{~h}$ at $37^{\circ} \mathrm{C}$. The plugs were

${ }^{1}$ Oxoid Ltd. Cambridge, UK.

${ }^{2}$ Bio-Rad Laboratories, Hercules, CA, USA. 
washed, placed in proteinase $\mathrm{K}$ solution and incubated at $50^{\circ} \mathrm{C}$ overnight. The plugs were washed five times with CHEF TE $1 \mathrm{X}$ buffer for $1 \mathrm{~h}$ each at room temperature. DNA was restricted for $20 \mathrm{~h}$ with $20 \mathrm{U}$ of $\mathrm{Xba \textrm {I }}$ enzyme at $37^{\circ} \mathrm{C}$. DNA was separated for $19 \mathrm{~h}$ by PFGE using $1.0 \%$ PFGE agarose in $0.5 \mathrm{X}$ TBE buffer under the following conditions: $14^{\circ} \mathrm{C}, 6 \mathrm{~V} / \mathrm{cm}$, 5-60 pulse times. A lambda ladder molecular weight marker ${ }^{2}$ was included in each gel. Gels were stained with ethidium bromide $(0.5 \mathrm{mg} / \mathrm{L})$ and then photographed under UV light.

Strains of $E$. coli were placed in groups of identical or related strains by comparing the banding patterns produced, using a combination of photographic visual inspection and computer analysis ${ }^{3}$. A pulsotype (PT) was defined as a unique electrophoretic banding pattern. Strains with identical restriction profiles were assigned as the same type and identified with a capital letter. Banding patterns presenting one to three differences among them were considered closely related and were assigned as subtypes (ST) indicated with a numeral suffix. Strains with more than three differences were considered to be different types (Tenover et al., 1995). The Dice formula was used to calculate the coefficients of pairwise similarity, and dendrograms were created by unweighted-pair group method (UPGMA) using arithmetic averages. The cluster cutoff was set at $80 \%$ similarity and all clusters were identified by arabic numerals.

\section{RESULTS AND DISCUSSION}

Sixty-nine $E$. coli strains were obtained from the 47 positive samples being 11 strains from the handlers, 33 from raw milk, and 25 from the minas frescal cheese. Out of the 92 samples collected from the handlers, $E$. coli was isolated in $11(12.0 \%)$ of them, and from the 24 samples of raw milk and cheese, it was found in 19 $(79.2 \%)$ and $17(70.8 \%)$ of them, respectively (Table 1).

De Buyser et al. (2001) evaluated 60 outbreaks of milk and dairy-transmitted diseases, in France and other countries, from 1980 to 1997, and determined that pathogenic E. coli was responsible for around $20.0 \%$ of the notified episodes and that cheese made from raw milk or non-specified milk type was the most common food involved.

In Brazil, the presence of pathogenic microorganisms has been observed in minas frescal cheese, and several studies confirmed the presence of fecal coliforms in this product in Poços de Caldas, MG (Almeida Filho and Nader Filho, 2002), Mato Grosso do Sul (Câmara et al., 2002), Rio de Janeiro, RJ (Araújo et al., 2002), Distrito Federal (Cardoso and Araújo, 2004), Serro, MG (Brant et al. 2007), and região central region (Paneto et al., 2007).

E. coli was isolated in $75.0 \%$ of the handlers and more frequently from the hands than from the nostrils. This finding was expected since the anterior nostrils are not described as a normal habitat for E. coli. Monteiro et al. (2001) isolated $E$. coli in $55.0 \%$ from hands of handlers in the State of Ceará. According to Araújo et al. (2002), the presence of fecal coliforms is evidence of poor hygiene practices, since the finding of a high number of these microorganisms is evidence that hands are not properly cleaned and a clear indication of risk for food contamination by fecal particles.

E. coli was isolated in $79.2 \%$ of the raw milk samples. Smaller percentages were obtained by Chye et al. (2004). They isolated this bacterium in $64.0 \%$ of the raw milk samples from dairy farms in Malaysia. Enteropathogenic microorganisms have been found in milk consumed without thermal treatment. Contamination during milking, as well as inadequate temperatures during storage and transportation, can result in high levels of pathogenic bacteria, which can represent a health risk to consumers (Araújo et al., 2002).

E. coli was isolated in $70.8 \%$ of the minas frescal samples. Similar results were found by Câmara et al. (2002) in Mato Grosso do Sul. Rocha et al. (2006) found that except one trademark, all six others presented contamination levels above those recommended by the Brazilian legislation.

The presence of $E$. coli is a clear evidence that the controls of raw material manufacturing processes and the final product is inefficient.

${ }^{3}$ BioNumerics, v. 4.0; Applied Maths - Kortrijk, Belgium. 
Table 1. Escherichia coli isolated from dairy staff, raw milk, and minas frescal cheese in a dairy plant

\begin{tabular}{|c|c|c|c|c|}
\hline \multirow{2}{*}{ Source } & \multirow{2}{*}{ Samples collected } & \multicolumn{2}{|c|}{ Positive samples } & \multirow{2}{*}{$\mathrm{N}^{\mathrm{o}}$ of strains } \\
\hline & & $\mathrm{N}^{\mathrm{o}}$ & $(\%)$ & \\
\hline Dairy staff, nostrils & 46 & 3 & 6.5 & 03 \\
\hline Dairy staff, hands & 46 & 8 & 17.4 & 08 \\
\hline Raw milk & 24 & 19 & 79.2 & 33 \\
\hline Cheese & 24 & 17 & 70.8 & 25 \\
\hline Total & 140 & 47 & - & 69 \\
\hline
\end{tabular}

Out of the 69 strains, three of them (two from milk and one from cheese) could not be typed, even after four repetitions. The genetic analysis of the 66 strains resulted in 61 different banding patterns varying from 9 to 17 distinct bands in the range of $679 \mathrm{~kb}$ to $48.5 \mathrm{~kb}$, showing a high level of genetic heterogeneity among the strains.

The dendrogram including all the genetic profiles was built on the basis of similarity levels (Fig. 1). The cluster cutoff was set at $80.0 \%$ similarity resulting in 57 clusters, numbered from 1 to 57 . The 66 typed E. coli strains were grouped in 60 pulsotypes (PTs) and one subtype (ST).

Ten different electrophoretic profiles were obtained from 11 strains from handlers, indicating the absence of an endemic strain among them. The results revealed that the workers harbored more than one clone in their hands and nostrils, except in one occasion, in which $\mathrm{M}^{2}$ presented the same clone in these sites (PT A) (Fig. 1).

Genetic typing of the 31 strains from the raw milk samples generated 30 different electrophoresis profiles, indicating the lack of an endemic strain. Only the PT T grouped two strains from a single milk sample (17la and 17lb) with identical band profiles, therefore, belonging to the same clone. The D pulsotype and the subtype D1 corresponded to two strains of the same raw milk sample (16la and 16lc), which were considered to be strongly related and are probably strains derived from the same clone (Fig. 1).

Picozzi et al. (2005), in Italy, used this technique to compare $12 \mathrm{E}$. coli strains isolated from cow milk and found different electrophoretic profiles, even when they used a $41.0 \%$ similarity level. This difference can be explained by the exposure of milk to several sources of contamination, such as the personnel involved in the milking process, utensils, and the farm environment, and the consequent poor hygiene/sanitation control of the milking activity in the farms that supply this product.

From the electrophoretic profiles obtained from the cheeses, there was no similarity since the 24 strains resulted in 24 different pulsotypes. Radu et al. (2002) found 28 different genotypic profiles in 28 strains of $E$. coli from samples of beef and poultry meat sold in Malaysia, using PFGE with a $90.0 \%$ similarity level.

After comparing the electrophoretic profiles and following the criteria established by Tenover et al. (1995), the 14qb (cheese) and 10m1 (hand) strains were considered identical. Therefore, it was possible to establish a contamination relationship of the final product by the handler (PT AA) (Fig. 1). This fact demonstrates that the handler represents a risk of bacterial transmission for the final product, especially when one considers that this small-scale dairy plant uses a manual process for producing minas frescal cheese.

Two pulsotypes contained identical strains isolated from milk and cheese: PT N (15q and 14l) and PT BF (10q and 11lc) (Fig. 1), according to criteria established by Tenover et al. (1995). Three cheeses strains were possibly related to three milk strains, thereby generating six distinct pulsotypes: PT J and PT K (13lb and 18q), PT V and PT W (14qa and 61), and PT Y and PT Z (15lb and 17qc) (Fig. 1). These results suggest that the raw material is the probable source of contamination of the final product. 


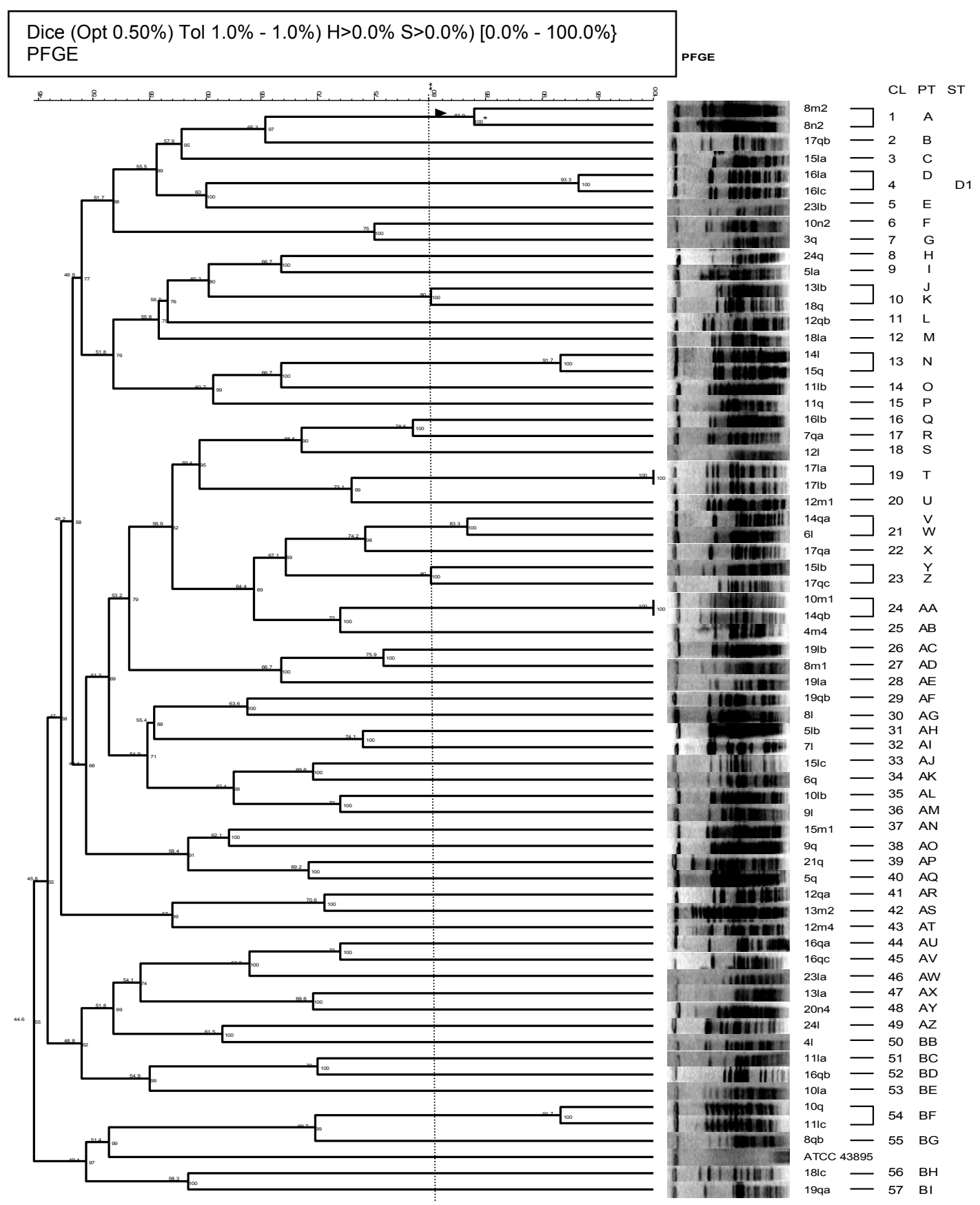

Figure 1. Clonal reletionships of 66 Escherichia coli strains established by Xba1 PFGE analysis. Clusters (CL) were labelled with arabic numbers, pulsotypes (PT), and subtypes (ST) with capital letters and letters and numbers, respectively.

- Similarity values, ${ }^{*}$ Cophenetic correlations, $* *$ Cutoff $(80 \%)$.

According to Radu et al. (2002), the genetic diversity observed among the $E$. coli isolated by means of molecular typing techniques contributed to the investigation of potential epidemiological problems caused by this pathogen. Subtyping of strains helps in contamination studies in the food industry, because critical points can be identified and 
appropriate measures implemented to guarantee product safety.

It was possible to observe that the use of a highly discriminatory technique, such as PFGE, made it possible to determine the genetic heterogeneity of $E$. coli strains, thus reflecting the complexity of this microorganism, especially in milk and cheese processing plants.

\section{ACKNOWLEDGEMENTS}

The authors would like to thank Drª . Ana Lúcia Sampaio Sgambatti de Andrade for her support in the molecular analysis.

\section{REFERENCES}

ALMEIDA FILHO, E.S.; NADER FILHO, A. Ocorrência de coliformes fecais e Escherichia coli em queijo tipo minas Frescal de produção artesanal, comercializado em Poços de Caldas, MG. Hig. Alim., v.16, p.71-73, 2002.

ARAÚJO, V.S.; PAGLIARES, V.A.; QUEIROZ, M.L. et al. Occurrence of Staphylococcus and enteropathogens in soft cheese commercialized in the city of Rio de Janeiro, Brazil. J. Appl. Microbiol., v.92, p.1172-1177, 2002.

BIDET, P.; KURKDJIAN, P.M.; GRIMONT, F. et al. Characterization of Escherichia coli $\mathrm{O}$ 157:H7 isolates causing haemolytic uraemic syndrome in France. J. Med. Microbiol., v.54, p.71-75, 2005.

BRANT, L.M.F.; FONSECA, L.M.; SILVA, M.C.C. Avaliação da qualidade microbiológica do queijo-de-minas artesanal do Serro-MG. Arq. Bras. Med. Vet. Zootec., v.59, p.1570-1574, 2007.

CÂMARA, S.A.V.; AMARAL, G.B.; MULLER, M.T. et al. Avaliação microbiológica de queijos tipo minas frescal artesanal, comercializados no mercado municipal de Campo Grande, Mato Grosso do Sul, 2000. Hig. Alim., v.16, p.32-36, 2002.

CARDOSO, L.; ARAÚJO, W.M.C. Parâmetros de qualidade em queijos comercializados no Distrito Federal, no período de 1997-2001. Hig. Alim., v.18, p.49-53, 2004.
CHYE, F.Y.; ABDULLAH, A.; AYOB, M.K. Bacteriological quality and safety of raw milk in Malaysia. Food Microbiol., v.21, p.535-541, 2004.

DE BUYSER, M.L.; DUFOUR, B.; MAIRE, M. et al. Implication of milk and milk products in food-borne diseases in France and in different industrialised countries. Int. J. Food. Microbiol., v.67, p.1-17, 2001.

FENG, P.; WEAGANT, S.D.; GRANT, M.A. Enumeration of Escherichia coli and the Coliform Bacteria. Bacteriological Analytical Manual online. Food \& Drug Administration (FDA), 2002. In: <http:// www.cfsan.fda.gov/>. Acessed in: 19 fev. 2003.

FOXMAN, B.; RILEY, L.W. Molecular epidemiology: focus on infection. Am. J. Epidemiol., v.153, p.1135-1141, 2001.

MIDURA, T.F.; BRYANT, R.G. Sampling plans, sample collection, shipment, and preparation for analysis. In:__ Compendium of methods for the microbiological examination for foods. Washington: APHA, 2001. p.13-23.

MONTEIRO, M.C.N.; TIMBÓ, M.O.P.P.; OLIVEIRA, S.C.A. et al. Controle higiênicosanitátio de manipuladores de alimentos de cozinhas industriais do estado do Ceará. Hig. Alim., v.15, p.90-93, 2001.

PANETO, B.R.; SHOCKEN-ITURRINO, R.P.; MACEDO, C. et al. Occurrence of toxigenic Escherichia coli in raw milk cheese in Brazil. Arq. Bras. Med. Vet. Zootec., v.59, p.508-512, 2007.

PFALLER, M.A.; HOLLIS, R.J.; SADER, H.S. Molecular Bology - PFGE Analysis of Chromossomal Restriction Fragments. In: INSEBERG H.D. Clinical microbiology procedures handbook. Washington: American Society for Microbiology, 1992. p.10.5.c.110.5.c. 11 .

PICOZZI, C.; FOSCHINO, R.; HEUVELINK, A. et al. Phenotypic and genotypic characterization of sorbitol-negative or slowfermenting (suspected O157) Escherichia coli isolated from milk samples in Lombardy region. Lett. Appl. Microbiol., v.40, p.491-496, 2005. 
RADU, S.; LING, O.W.; RUSUL, G. et al. Detection of Escherichia coli O157:H7 multiplex PCR and their characterization by plasmid profiling, antimicrobial resistance, RAPD and PFGE analyses. J. Microbiol. Meth., v.46, p.131-139, 2002.

RITTER, R.; SANTOS, D.; BERGMANN, G.P. Análise da qualidade microbiológica de queijo colonial, não pasteurizado, produzido $\mathrm{e}$ comercializado por pequenos produtores, no Rio Grande do Sul. Hig. Alim., v.15, p.51-55, 2001.

ROCHA, J.S.; BURITI, F.C.A.; SAAD, S.M.I. Condições de processamento e comercialização de queijo-de-minas frescal. Arq. Bras. Med. Vet. Zootec., v.58, p.263-272, 2006.
TENOVER, F.C.; ARBEIT, R.D.; GOERING, R.V. et al. Interpreting chromosomal DNA restriction patterns produced by pulsed-field gel electrophoresis: criteria for bacterial strain typing. J. Clin. Microbiol., v.33, p.2233-39, 1995.

VANDENBERGH, M.F.Q.; YZERMAN, E.P.F.; VAN BELKUM, A. et al. Follow-up of Staphylococcus aureus nasal carriage after 8 years: redefining the persistent carrier state. $J$. Clin. Microbiol., v.37, p.3133-3140, 1999. 